\title{
ANALISIS PERTUMBUHAN SEKTOR PERBANKAN DI INDONESIA TAHUN 2001-2008
}

\author{
Oleh: \\ Asmirawati \\ Staff PT. Bank Mega Kota Baru Kalimantan Tengah \\ E-mail/No. Hp: - /085755272767
}

\begin{abstract}
Intention of this research is to know level of growth of banking credit in Indonesia and know macro variable influence that is resident amounts, earnings of perkapita and amount of money supplies to growth of banking credit. Analyzer applied to know resident growth influence, income percapita, amount of money supplies to growth of credit is doubled linear regression test with statistical test two directions that is T test and $F$ test and test ekonometrika that is classic assumption test (multikolinierity test, heteroskedastisity test, autocorrelation test). Result of research at doubled linear regression shows growth of number of residents to growth of credit influential significant. while earnings growth of percapita doesn't have an effect on signif " it to growth of credit and growth of amount of money supplies influential significant to growth of credit. Based on conclusion to macro variable of chartered investment counsel can be cought up with growth of credit as according to ability of Negara to be realized secure and prosperous public.
\end{abstract}

Keywords: Growth of Banking Credit, Macro Variable, Indonesia

\section{PENDAHULUAN}

Kondisi dunia perbankan di Indonesia telah banyak mengalami perubahan dari waku kewaktu. Perubahan ini selain disebabkan oleh perkembangan internal dunia perbankan, juga tidak lepas dari pengaruh perkembangan di luar dunia bank, seperti sektor riil dalam perekonomian, politik, sosial, hukum, pertahanan, dan keamanan. Dimulai dari tahun 1983 ketika berbagai macam deregulasi dan penerapan kebijakan yang terkait dengan sektor moneter riil telah menyebabkan sektor perbankan mempunyai kemampuan untuk meningkatkan kinerja ekonomi makro di Indonesia. Bisnis perbankan ini berkembang pesat pada kurun waktu 1988-1996, namun pada pertengahan 1997, industri perbankan mengalami kemunduran total akibat terjadinya krisis moneter dan krisis ekonomi yang melanda Indonesia.

Usaha bank selalu berkaitan dengan keuangan, yaitu: menghimpun dana, menyalurkan dana, dan memberikan jasa bank lainnya. Dengan demikian sebagai suatu badan berfungsi sebagai perantara keuangan (financial intermediary) dari dua pihak, yaitu pihak yang kelebihan dana (surplus unit), dan pihak yang kekurangan dana ( deficit unit ). Hal ini juga yang menyebabkan lembaga bank disebut sebagai lembaga kepercayaan. (kasmir, 2000:27) artinya pihak yang kelebihan dana mempercayakan sepenuhnya kepada bank untuk mengelola dananya termasuk menyalurkan kepada pihak yang kekurangan atau memerlukan dana berupa kredit.

Pada tahun 2008 kondisi perbankan nasional dapat dikatakan bahwa perkembangan indikator- 
indikator perbankan cukup menggembirakan, melanjutkan kecenderungan perbaikan yang telah berlangsung setidaknya sejak tahun 2004. Industri perbankan semakin sehat dan bermanfaat, ternyata juga telah berkembang semakin kokoh sebagaimana yang ditunjukkan oleh kemampuannya dalam menyerap berbagai gejolak dalam perekonomian. Dilihat dari angka pertumbuhan kredit, maka kredit konsumsi adalah jenis kredit yang mengalami lonjakan pertumbuhan terbesar dari $9,51 \%$ pada 2006 menjadi $24,84 \%$ di 2007, sedangkan pertumbuhan kredit modal kerja dari $16,98 \%$ menjadi $28,57 \%$, dan kredit investasi dari $12,51 \%$ menjadi $23,15 \%$.

Karena akan membahas tentang pertumbuhan perbankan dalam variabel ekonomi makro, maka dalam proposal ini dibahas tentang variabel-variabel makro yang berhubungan dengan pertumbuhan perbankan. Berdasarkan penjelasan diatas maka penelitian ini bertujuan untuk mengetahui Seberapa besar tingkat pertumbuhan sektor perbankan di Indonesia tahun 2001-2008 dan Seberapa besar pengaruh variabel jumlah penduduk, pendapatan perkapita, dan jumlah uang beredar terhadap pertumbuhan sektor perbankan.

\section{TINJAUAN PUSTAKA}

Pada perbaikan perekonomian nasional harus di lakukan serentak dengan perbaikan sektor perbankan. Adapun faktor yang mempengaruhi pertumbuhan perbankan sebagai berikut: Pertama, Kredit, (Rimsky, Judisseno: 2003:135) Meningkatnya kegiatan perekonomian berdampak langsung terhadap peningkatan usaha dan kebutuhan manusia. Peningkatan tersebut tidak selalu diikuti oleh kemampuan financial dari pelaku ekonomi, oleh karena itu, kredit selalu dibutuhkan oleh masyarakat sebagai pelaku ekonomi. Kedua, Jumlah Penduduk. Penduduk (population) adalah semua orang yang menetap di suatu wilayah tertentu dalam jangka waktu tertentu. Jumlah penduduk suatu negara dapat diketahui melalui beberapa cara yaitu sensus penduduk, survey penduduk dan registrasi penduduk:

\section{Pendapatan perkapita} (percapita income) adalah pendapatan rata-rata penduduk suatu negara pada suatu periode tertentu, yang biasanya satu tahun. Pendapatan per kapita bisa juga diartikan sebagai jumlah dari nilai barang dan jasa rata-rata yang tersedia bagi setiap penduduk suatu negara pada suatu periode tertentu. Pendapatan per kapita diperoleh dari pendapatan nasional pada tahun tertentu dibagi dengan jumlah penduduk suatu negara pada tahun tersebut.

Kemampuan bank dalam mencetak uang mempunyai peranan dalam memenuhi permintaan kredit bank. Akan tetapi kemampuan menciptakan kredit dibatasi oleh tingkat keuntungan yang diharapkan oleh bank atas pemegang kekayaannya.

\section{METODE PENELITIAN}

Data yang digunakan dalam penelitian ini diperoleh dari Badan Pusat Statistik dan Bank Indonesia. Definisi Operasional Variabel dalam penelitian ini, Kredit (Y) yaitu Pertumbuhan sektor perbankan merupakan variabel terikat yang menunjukkan besarnya pertumbuhan perbankan yang dilihat dari posisi kredit rupiah bank umum menurut kelompok bank dari tahun 2001-2008.

Jumlah penduduk merupakan variabel bebas yang menunjukkan besarnya jumlah penduduk yang dilihat dari tingkat penduduk berumur 15 tahun keatas yang bekerja selama seminggu yang lalu menurut status pekerjaan utama dan lapangan pekerjaan utama dari tahun 2001-2008. 
Pendapatan perkapita merupakan variabel bebas yang diambil dari Produk Domestik Bruto (PDB) dibagi dengan jumlah penduduk pada tahun tersebut, Dimana PDB yang menunjukkan harga konstan dari tahun 2001-2008 yang berpengaruh terhadap pertumbuhan perbankan.

Jumlah uang beredar merupakan variabel bebas yang menunjukkan besarnya jumlah M2 pada tahun 20012008.

Analisis data dalam penelitian ini yaitu Analisis Linier Berganda dan untuk menguji hipotesis digunakan Uji T, Uji F disertai Koefisien Determinasi $\left(\mathrm{R}^{2}\right)$. Adapun model penelitian ini sebagai berikut:

$\mathrm{Y}=\beta_{0}+\beta_{1} \mathrm{X}_{1}+\beta_{2} \mathrm{X}_{2}+\beta_{3} \mathrm{X}_{3}+\mathrm{e}$

Dimana: $\mathrm{Y}=$ Kredit; $\mathrm{X}_{1}=$ Jumlah penduduk; $\mathrm{X}_{2}=$ Pendapatan perkapita; $\mathrm{X}_{3}=$ Jumlah uang beredar.

\section{PEMBAHASAN}

Bank adalah lembaga keuangan yang fungsi utamanya menyediakan jasa intermediasi \& jasa keuangan lainnya kepada perusahaan dan rumah tangga, dengan tujuan untuk memaksimumkan kekayaan pemilik.

Kurangnya kredit perbankan yang mengalir ke sektor riil selama ini bisa juga dikarenakan oleh sulitnya akses, dalam arti persyaratan terlalu ketat sehingga banyak pengusaha yang memilih sumber-sumber dana alternatif lainnya, seperti yang telah disebut sebelumnya di atas. Hal ini memang sangat masuk akal, karena di satu pihak, perbankan tidak mungkin secara terangterangan menutup pintu bagi dunia usaha yang ingin pinjam dana untuk investasi atau modal kerja. Namun perbankan punya keinginan, yakni lebih memilih menyalurkan kredit konsumen dan/atau menanam di SBI atau SUN. Agar pilihan ini terpenuhi, maka perbankan memperketat syarat-syarat meminjam untuk maksud bisnis, apalagi investasi, sementara memperingan syarat-syarat meminjam untuk maksud konsumsi (misalnya untuk beli mobil atau rumah). Diskriminiasi dalam persyaratan kredit ini yang lebih berat ke dunia usaha bisa saja dilihat dari sudut pandang pengusaha sebagai terbatasnya akses ke kredit perbankan.

Stabilitas perekonomian merupakan prasyarat dasar untuk tercapainya peningkatan kesejahteraan rakyat melalui pertumbuhan yang tinggi dan peningkatan kualitas pertumbuhan. Stabilitas perekonomian sangat penting untuk memberikan kapasitas berusaha bagi para pelaku ekonomi. Stabilitas ekonomi makro dicapai ketika hubungan variable ekonomi makro yang utama berada dalam keseimbangan.

Mengingat pentingnya stabilitas ekonomi makro bagi kelancaran dan pencapaian sasaran pembangunan nasional, Pemerintah bertekad untuk terus menciptakan dan memantapkan stabilitas ekonomi makro. Salah satu arah kerangka ekonomi makro dalam jangka menengah adalah untuk menjaga stabilitas ekonomi makro dan mencegah timbulnya fluktuasi yang berlebihan di dalam perekonomian. Stabilitas ekonomi makro tidak hanya tergantung pada pengelolaan besaran ekonomi makro semata, tetapi juga tergantung kepada struktur pasar dan sektor-sektor.

Berdasarkan data pada tabel 1 . pertumbuhan kredit perbankan mengalami naik turun yang sangat tajam, pada tahun 2000 pertumbuhan kredit sebesar $8,51 \%$ meningkat pada pada tahun 2001 sebesar 32,88\%, sedangkan pada tahun 2003 pertumbuhan kredit menurun sebesar $25,81 \%$ dari tahun sebelunnya tahun 2002 sebesar $34,18 \%$, kemudian terus meningkat pada tahun berikutnya sebesar $28,32 \%$ pada tahun 2004 dan 29,07\% pada tahun 2005, tetapi pada tahun 2006 menurun dengan 
tajam sebesar 12,84\%, dan terus meningkat pada tahun 2007 sebesar 24,10\% dan tahun 2008 sebesar 32,27\%. Tabel 1. Pertumbuhan Jumlah Kredit di Indonesia $(\%)$

\begin{tabular}{ll}
\hline Tahun & Kredit \\
\hline 2000 & 8.51 \\
2001 & 32.88 \\
2002 & 34.17 \\
2003 & 25.81 \\
2004 & 28.32 \\
2005 & 29.07 \\
2006 & 12.84 \\
2007 & 24.10 \\
2008 & 33.27 \\
\hline
\end{tabular}

Sumber: Bank Indonesia (diolah)

Pertumbuhan penduduk Indonesia (Tabel 2) mengalami siklus naik turun. Terbukti pada tahun 2000 sebesar $1,15 \%$ menurun pada tahun 2001 sebesar $0,90 \%$ tetapi pada tahun 2002 kembali menurun sebesar -0,94, kemudian pada tahun 2004 meningkat tajam mencapai 3,24\% tetapi pada tahun 2004, penurunan kembali terjadi pada tahun 2005 sebesar $1,31 \%$ dan tahun 2006 sebesar 0,54\%, dan pada tahun 2007 meningkat kembali sebesar $4,69 \%$ dan kembali menurun sebesar $2,62 \%$ pada tahun 2008 .

Tabel 2. Pertumbuhan Jumlah Penduduk

\begin{tabular}{cc}
\hline Tahun & Jumlah Penduduk \\
\hline 2000 & 1.15 \\
2001 & 0.90 \\
2002 & 1.10 \\
2003 & -0.94 \\
2004 & 3.24 \\
2005 & 1.31 \\
2006 & 0.54 \\
2007 & 4.69 \\
2008 & 2.62 \\
\hline
\end{tabular}

di Indonesia (\%)

Sumber: Bank Indonesia (diolah)

Pertumbuhan pendapatan perkapita
(Tabel 3) menujukkan bahwa setiap tahunnya terjadi kenaikan dan penurunan, pada tahun 2001 pertumbuhan pendapatan perkapita menurun sebesar 2,39\% dari tahun 2000 sebesar $4,06 \%$, kemudian pada tahun 2002 terjadi peningkatan meskipun masih relative kecil sebesar 2,66\%, pada tahun 2003 kembali meningkat sebesar $5,21 \%$, akhirnya peningkatan tertinggi terjadi pada tahun 2004 sebesar $261,90 \%$, tetapi terjadi penurunan lagi sebesar 3,93\% pada tahun 2005, kemudian menurun lagi pada tahun 2006 sebesar 4,99\% dan menurun lagi sebesar $1,59 \%$ pada tahun 2007, terakhir tahun 2008 kembali meningkat sebesar 3,30\%.

Tabel 3. Pertumbuhan Pendapatan Perkapita di Indonesia (\%)

\begin{tabular}{cc}
\hline Tahun & Perkapita \\
\hline 2000 & 4.06 \\
2001 & 2.39 \\
2002 & 2.66 \\
2003 & 5.21 \\
2004 & 261.90 \\
2005 & 3.93 \\
2006 & 4.99 \\
2007 & 1.59 \\
2008 & 3.30 \\
\hline
\end{tabular}

Sumber: BPS (diolah)

Pertumbuhan jumlah uang beredar juga terjadi kenaikan dan penurunan pada tabel 4, pada tahun 2001 turun sebesar 12,99\% dari tahun 2000 sebesar $15,60 \%$, pada tahun berikutnya setiap tahun terjadi perubahan naik turun, pada tahun 2002 sebesar $4,72 \%$ dan pada tahun 2003 meningkat sebesar 9,37\%, kemudian tahun 2004 turun kembali sebesar 6,91\%, pada tahun 2005 peningkatan jumlah uang beredar cukup tinggi sebesar $16,42 \%$ dan pada tahun 2006 penurunan cukup rendah sebesar $14,87 \%$, meningkat kembali pada tahun 2007 sebesar 18,89\% dan akhirnya pada 
tahun 2008 kembali turun sebesar $14,65 \%$.

Tabel 4. Pertumbuhan Jumlah Uang

\begin{tabular}{cc}
\hline Tahun & Jumlah Uang Beredar \\
\hline 2000 & 15.60 \\
2001 & 12.99 \\
2002 & 4.72 \\
2003 & 9.37 \\
2004 & 6.91 \\
2005 & 16.42 \\
2006 & 14.87 \\
2007 & 18.89 \\
2008 & 14.65 \\
\hline
\end{tabular}

Beredar di Indonesia (\%)

Sumber: Bank Indonesia (diolah)

Penelitian ini menggunakan data kuartalan dari periode 2001-2008 dikumpulkan dalam bentuk table-tabel diatas. Adapun alat yang digunakan dalam menganalisis dengan menggunakan alat analisis regresi linier berganda metode kuadrat terkecil biasa. Tujuan analisis ini untuk mengetahui nilai-nilai regresi dari masingmasingvariabel sehingga dapat diketahui pengaruhnya.

Hasil regresi pertumbuhan jumlah penduduk, pertumbuhan pendapatan perkapita, pertumbuhan JUB terhadap pertumbuhan kredit, sehingga dalam persamaan ini dapat ditulis sebagai berikut:

Tabel 5. Pengaruh Masing-Masing Variabel Bebas terhadap Variabel Terikat Dependent Variable: Y

\begin{tabular}{crlrr}
\multicolumn{1}{c}{ Variable } & Coefficient & Std. Error & t-Statistic & Prob. \\
\hline C & 8.612922 & 1.197161 & 7.194454 & 0.0000 \\
X1 & 2.492544 & 0.943256 & 2.642489 & 0.0133 \\
X2 & -0.040140 & 0.020472 & -1.960705 & 0.0599 \\
X3 & -0.926901 & 0.370051 & -2.504795 & 0.0183 \\
R-squared & 0.249096 & Mean dependent var & 6.493438 \\
Adjusted R-squared & 0.168641 & S.D. dependent var & 2.934313 \\
S.E. of regression & 2.675473 & Akaike info criterion & 4.922598 \\
Sum squared resid & 200.4284 & Schwarz criterion & 5.105815 \\
Log likelihood & -74.76157 & F-statistic & 3.096122 \\
Durbin-Watson stat & 1.163234 & Prob(F-statistic) & 0.042836 \\
\hline
\end{tabular}


$\beta_{3} \quad\left(\mathrm{X}_{3}\right)=-0.9269$ koefisien variabel pertumbuhan JUB (X3) sebesar -0.9269 berarti ada pengaruh negative antara pertumbuhan JUB terhadap pertumbuhan kredit sebesar -0.9269, apabila terjadi peningkatan prosentae pertumbuhan JUB sebesar $1 \%$ maka pertumbuhan kredit akan naik sebesar 0,92696 sebaliknya apabila prosentae pertumbuhan JUB mengalami penurunan $1 \%$ maka pertumbuhan kredit akan turun sebesar 0,92696.

Dengan demikian dapat diketahui pengaruh Pertumbuhan penduduk (X1) secara signifikan terhadap pertumbuhan kredit (Y). Dapat dilihat dari nilai thitung yang lebih besar dari t-tabel atau dapat dilihat dari nilai probabilitasnya, yaitu apabila probabilitas atau tingkat signifikansinya dibawah 0.05 maka dapat dikatakan variabel tersebut lolos uji $\mathrm{t}$ dan nilai probabilitasnya sebesar 0.0133. Koefisien variabel sebesar 2.492544 menunjukkan bahwa apabila prosentase pertumbuhan penduduk naik sebesar $1 \%$ akan mengakibatkan kenaikan pada prosentae pertumbuhan kredit sebesar $2.492544 \%$.

Pengaruh Pertumbuhan pendapatan perkapita (X2) tidak berpengaruh secara signifikan terhadap pertumbuhan kredit (Y). Dapat dilihat dari nilai t hitung yang lebih kecil dari t tabel atau dapat dilihat dari nilai probabilitasnya, yaitu apabila probabilitas atau tingkat signifikansinya dibawah 0.05 maka dapat dikatakan variabel tersebut lolos uji $\mathrm{t}$ dan nilai probabilitasnya sebesar 0.0599 . Koefisien variabel sebesar -0.040140 menunjukkan bahwa apabila prosentae pertumbuhan pendapatan perkapita naik sebesar $1 \%$ akan mengakibatkan kenaikan pada prosentase pertumbuhan kredit sebesar 4,01\%.

Pengaruh Pertumbuhan Jumlah Uang Beredar (X3) berpengaruh secara signifikan terhadap pertumbuhan kredit
(Y). Dapat dilihat dari nilai t hitung yang lebih besar dari t tabel atau dapat dilihat dari nilai probabilitasnya, yaitu apabila probabilitas atau tingkat signifikansinya dibawah 0.05 maka dapat dikatakan variabel tersebut lolos uji t dan nilai probabilitasnya sebesar 0.0183 . Koefisien variabel sebesar -0.926901 menunjukkan bahwa apabila pertumbuhan prosentae jumlah uang beredar naik sebesar $1 \%$ akan mengakibatkan kenaikan pada prosentase pertumbuhan kredit sebesar 92,69\% cateris paribus.

\section{PENUTUP}

Pertumbuhan jumlah penduduk mempunyai pengaruh signifikan terhadap pertumbuhan kredit sebesar 2.6425 karna nilai t-hitung lebih besar dari t-tabel sebesar 2.048, atau dilhat dari nilai profitabilitasnya dibawah 0.05 sebesar 0.0133 .

Pertumbuhan pendapatan perkapita sebesar -1.9607 terhadap pertumbuhan kredit tidak berpengaruh signifikan karna nilai t-hitung lebih kecil dari pada t-tabel sebesar 2.028, atau dilihat dari nialai profitabilitasnya dibawah 0.05 sebesar 0.0599 .

Pertumbuhan jumlah uang beredar mempunyai pengaruh signifikan terhadap pertumbuhan kredit sebesar 2,5048 karna nilai t-hitung lebih besar dari t-tabel sebesar 2.048, atau dilihat dari nilai profitabilitasnya dibawah 0.05 sebesar 0.0183 .

Untuk mewujudkan perbankan Indonesia yang lebih kokoh, perbaikan harus dilakukan di berbagai bidang, tantangan yang dihadapi perbankan dalam beberapa tahun belakangan ini salah satunya adalah kapasitas pertumbuhan kredit perbankan yang masih rendah untuk mencapai pertumbuhan ekonomi yang cukup tinggi dalam waktu lima tahun ke depan, 
diperlukan pertumbuhan kredit perbankan yang cukup besar.

\section{DAFTAR PUSTAKA}

Bank Indonesia. Statistik Ekonomi Keuangan Indonesia, Jakarta (Dalam Beberapa Terbitan).

Hastuty. 2006. Pengaruh VariabelVariabel Makro Ekonomi Terhadap Perkembangan Perbankan di Indonesia, Universitas Muhammadiyah Malang.

I Putu Sukma, Rahadhian. 2009. Tinjauan Pelaksanaan Perjanjian Kredit Bank di BPR BKK Capem Baturetno Kabupaten Wonogiri. Universitas Muhammadiyah Surakarta

Iswardono. 1999. Uang dan Bank, Edisi Keempat. BPFE, Yogyakarta.

Judsseno K Rimsky. 2002. Sistem Moneter dan Perbankan di Indonesia, Edisi Pertama, PT. Gramedia Pustaka utama, Jakarta.

Kasmir. 2004. Dasar-Dasar Perbankan, Edisi Pertama, Raja Grafindo Persada Jakarta.

Kuncoro, Mudrajad. 2007. Metode Kuantitatif: Teori dan Aplikasi Untuk Bisnis Dan Ekonomi, UPP STIM YKPN, Yogyakarta.

Mangkoesoebroto Guritno, Algifari. 1998. Teori Makro Ekonomi, Edisi Ketiga, STIE YKPN, Yogyakarta.

Murni Asfia. 2006. Ekonomika Makro, Edisi Pertama, PT Refika Aditama Bandung.
Sukarman Widigdo. 1999. Upaya Penyehatan Perbankan dan Sektor Riil, Bisnis\& Ekonomi Politik Quarterly Review of the Indonesia Economy, Vol.3, No.1, hal.21. Jakarta.

Sadono Sukirno. 2000. Pengantar Makroekonomi, edisi keempat, Raja Grafindo Persada, Jakarta.

Sutojo Siswanto. 2007. Manajemen Terapan Bank, Cetakan Pertama, Lembaga PPM, Jakarta.

Wijaya Krisna. 2000. Reformasi Perbankan Nasional catatan kolom demi kolom; Kompas, Jakarta.

http://wartawarga.gunadarma.ac.id20100 1laju-pertumbuhan-pendudukindonesia pertahun 
